\title{
Quantitative analysis of calcareous nannofossil assemblages across the Campanian/Maastrichtian boundary interval at Kladorub (NW Bulgaria): preliminary results
}

\author{
Количествен анализ на асоциациите от варовити нанофосили в \\ Кампан-Мастрихтския граничен интервал в Кладоруб (С3 България): \\ предварителни резултати
}

\author{
Georgi Granchovski \\ Георги Грънчовски
}

Geological Institute, Bulgarian Academy of Sciences, Acad. G. Bonchev Str., Bl. 24, 1113 Sofia; E-mail: georgi2801@geology.bas.bg

\begin{abstract}
An investigation of the variations in calcareous nannofossil abundances across the Campanian/Maastrichtian boundary interval at Kladorub (NW Bulgaria) has been carried out. The section has an established detailed biostratigraphic framework, based on calcareous nannofossils, and also contains the Campanian-Maastrichtian Boundary Event. The analysis shows that the nannofloras are dominated by Prediscosphaera cretacea, followed by Watznaueria barnesiae, Micula staurophora, Arkhangelskiella spp. and Cribrosphaerella ehrenbergii.
\end{abstract}

Keywords: calcareous nannofossils, nannofossil abundance fluctuations, Campanian/Maastrichtian boundary interval, Kladorub, Bulgaria.

\section{Introduction}

Although the Late Cretaceous is known to be one of the warmest intervals in the last 200 million years of Earth's history, recent studies have shown that a longterm cooling trend commenced in the Campanian (see Razmjooei et al., 2020, and references therein). Over this trend, several short-term cooling and warming episodes were superimposed during the late Campanian-Maastrichtian (ibid.). Aside from stable isotope analyses, the abundant specialised literature shows that variations in calcareous nannofloras have also been a contributing factor in outlining these climatic episodes during the Late Cretaceous. Quantitative studies on Late Cretaceous calcareous nannofossil assemblages in Bulgaria, however, are still rare, which prompted the present investigation.

Recently, Granchovski (2019) provided a detailed, high-resolution calcareous nannofossil biostratigraphy for the Upper Cretaceous portion of the Kladorub Formation at Kladorub (NW Bulgaria), which spans the interval from the upper Campanian (UC15 $\mathrm{d}^{\mathrm{TP}}$ ) to the end-Maastrichtian (UC20d ${ }^{\mathrm{TP}}$ ). Stoykova et al. (2020) published stable isotope curves, derived from benthic foraminifera, for the section and recognised the presence of the Campanian-Maastrichtian Boundary Event (CMBE). The present account is a continuation of these studies. Its aim is to give preliminary data on the quantitative analysis of calcareous nannofossil assemblages across the CMBE at Kladorub.

\section{Geological setting}

According to current geodynamic models, the sediments of the Kladorub Formation are thought to have been deposited on the continental slope of a deep-water back-arc basin in the western periphery of the Moesian Platform (Dabovski et al., 2009). In terms of tectonics, its distribution is restricted to the limits of the Kula tectonic unit of Dabovski and Zagorchev (2009), which is a para-autochthonous unit regarded as a part of the South Carpathian orogenic system (ibid.).

Section Kladorub is situated $\sim 2.5 \mathrm{~km}$ to the southeast of Kladorub village. It is comprised of grey to grey-greenish silty to fine-sandy marlstones, interbedded with rare marly limestones and sandstones. It spans the interval from the upper Campanian (pars.) to the Ypresian (pars.) (see Granchovski, 2019, and references therein). Detailed calcareous nannofossil biostratigraphy of the Upper Cretaceous part of the 
section, together with illustrations of the majority of the identified species, was published by Granchovski (2019). Recently, Stoykova et al. (2020) documented the CMBE at Kladorub, based on stable isotope data derived from benthic foraminifera.

\section{Material and methods}

Out of 164 calcareous nannofossil samples investigated for biostratigraphic purposes (Granchovski, 2019), a total of 71 slides, taken with a $50-\mathrm{cm}$ resolution, were chosen for the present study. They span the interval from $33.5 \mathrm{~m}$ to $75.5 \mathrm{~m}$ (upper part of $\mathrm{UC} 15 \mathrm{e}^{\mathrm{TP}}$-top UC18), which encompasses the CMBE (Stoykova et al., 2020). Nannofloras were examined in simple smear-slides, made following the methodology described by Bown and Young (1998). These were viewed at $1250 \times$ magnification, using an oil-objective lens $(\times 100)$ on a Zeiss Axioskop 40 transmitting lightmicroscope. Specimens were counted in randomly selected fields of view from both the central and the peripheral areas of the slides. In samples containing fragmented specimens, identifiable coccoliths were counted as one specimen only if at least one-half of the coccolith was preserved. Relative abundances for each taxon were estimated over 400 specimens. Relative abundances of selected taxa are shown in Fig. 1.

The biostratigraphic framework adopted herein is that of Granchovski (2019), which is based on Burnett's (1998) global UC zonation, as supplemented by Thibault (2016) for UC16.

\section{Results and discussion}

One hundred and nine calcareous nannoplankton species have been recognised in the studied interval. Persample species richness varies from 68 to 86 (avg. 77). Preservation is predominantly moderate, with some secondary calcite overgrowth and/or dissolution apparent. Holococcoliths and small coccoliths are reasonably consistently present, which suggests that diagenesis has not had a too deleterious impact on the assemblages.

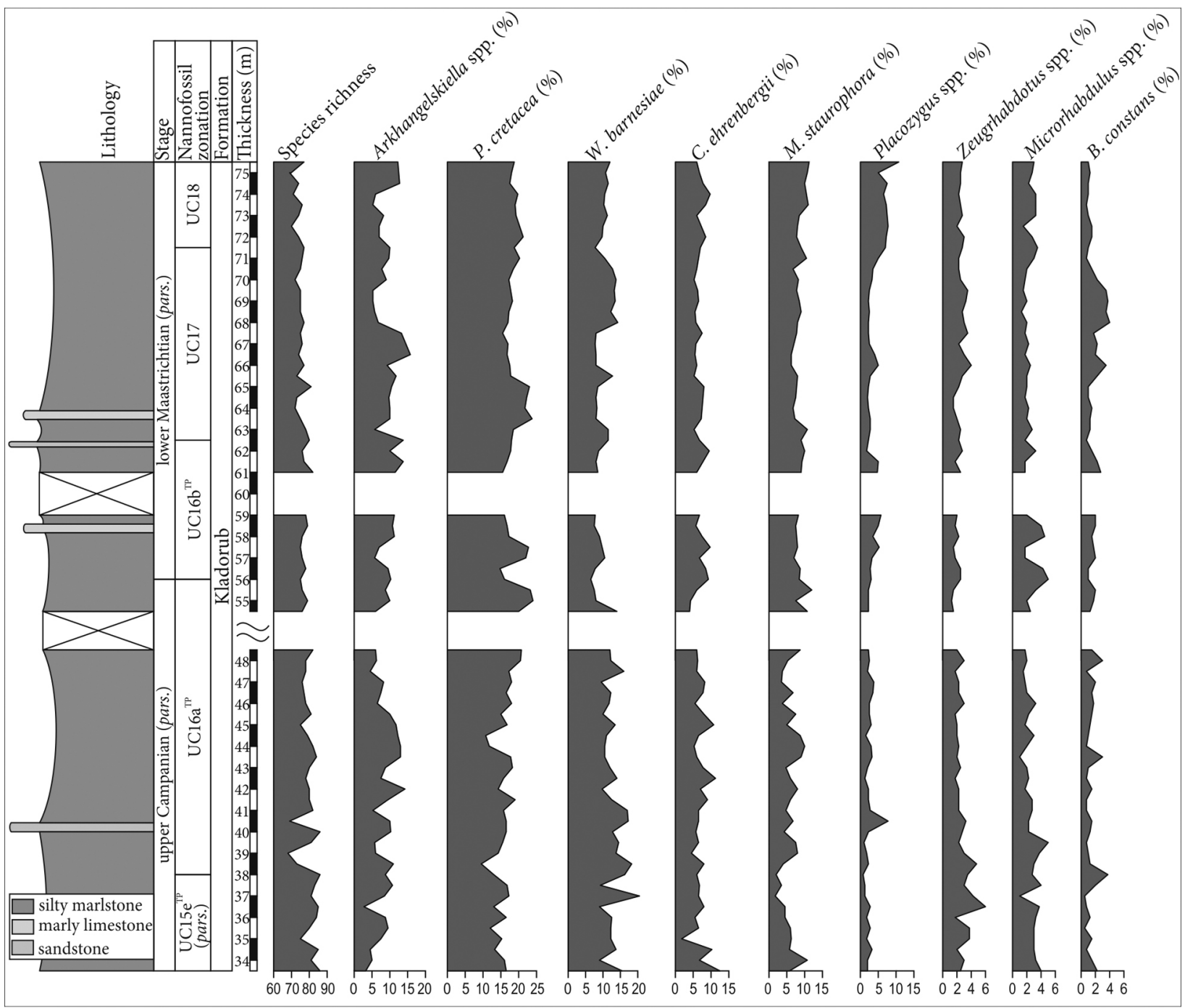

Fig. 1. Species richness and relative abundances (in \%) of selected calcareous nannoplankton taxa from the Campanian/Maastrichtian boundary interval at Kladorub. Nannofossil biostratigraphy after Granchovski (2019). 
The most abundant genus is Prediscosphaera, which accounts for $12.5 \%$ (at $44.5 \mathrm{~m}$ ) to $27 \%$ (at $63.5 \mathrm{~m}$ ) of the assemblages (avg. 20.79\%). It is represented by $P$. arkhangelskyi (only in the lowest two samples), $P$. cretacea, $P$. grandis, $P$. majungae, $P$. mgayae (only from $57.5 \mathrm{~m}$ to $75.5 \mathrm{~m}$ ), P. microrhabdulina, $P$. ponticula, $P$. spinosa and $P$. stoveri. Of these, $P$. cretacea distinctly dominates (avg. $17.48 \%$ ), varying from $9.5 \%$ (at $38.5 \mathrm{~m}$ ) to $24 \%$ (at $55 \mathrm{~m}$ ). This species shows a trend towards slightly increased abundances in the lower Maastrichtian (avg. 18.61\%) compared to the upper Campanian (avg. 16.31\%) (Fig. 1).

Watznaueria comprises from $7.25 \%$ (at $56 \mathrm{~m}$ ) to $22.25 \%$ (at $37 \mathrm{~m}$ ) of the nannofossil assemblages, with an average of $12.14 \%$. It includes $W$. barnesiae, $W$. biporta, W. fossacincta, W. manivitiae and $W$. ovata. The most abundant species is $W$. barnesiae (avg. $11.25 \%$ ) and ranges from $6.5 \%$ (at $56 \mathrm{~m}$ ) to $20.5 \%$ (at $37 \%$ ). Its abundance slightly decreases in the lower Maastrichtian (avg. 10.05\%, compared to an average of $12.49 \%$ in upper Campanian samples) (Fig. 1). There is a slight negative correlation between $W$. barnesiae and $P$. cretacea.

The third most abundant genus is Arkhangelskiella, which varies from $2.75 \%$ (at $36.5 \mathrm{~m}$ ) to $15.75 \%$ (at $66.5 \mathrm{~m}$ ), with an average of $8.97 \%$ (Fig. 1). It is represented by $A$. confusa (dominant; avg. $7.22 \%$ ) and A. cymbiformis (avg. $1.75 \%$ ). Their quantitative presence in lower Maastrichtian samples is slightly higher than in upper Campanian ones. Arkhangelskiella confusa reaches its peak abundance $(13 \%$ at $66.5 \mathrm{~m})$ in mid-UC17, whereas A. cymbiformis peaks in mid$\mathrm{UC} 18(7 \%$ at $74.5 \mathrm{~m})$. There is a slight negative correlation between Arkhangelskiella spp. and P. cretacea, whereas the negative correlation between Arkhangelskiella spp. and $W$. barnesiae is more pronounced.

The genus Micula is represented by M. staurophora (dominant), M. concava, M. cubiformis and M. swastica, with an average of $8.49 \%$ (Fig. 1). Its abundance varies from $3 \%$ (at $37 \mathrm{~m}$ ) to $13 \%$ (at $34 \mathrm{~m}$ ). Micula staurophora, ranging from $1.75 \%$ (at $37 \mathrm{~m}$ ) to $12 \%$ (at $55.5 \mathrm{~m}, 50 \mathrm{~cm}$ below the Campanian/Maastrichtian boundary), averages at $7.42 \%$. Its quantitative presence in Maastrichtian samples (avg. 8.48\%) is higher than in Campanian ones (avg. $6.33 \%$ ). There is a positive correlation between M. staurophora and Arkhangelskiella spp. and a relatively strong inverse correlation between $M$. staurophora and $W$. barnesiae.

Cribrosphaerella ehrenbergii (avg. 6.94\%) varies from $1.75 \%$ (at $35 \mathrm{~m}$ ) to $12.5 \%$ (at $35.5 \%$ ) (Fig. 1). Recently, Razmjooei et al. (2020) considered this species, together with Arkhangelskiella spp., as the best cool-water indicator in the Zagros Basin (Iran). Interestingly, at Kladorub, C. ehrenbergii correlates negatively with Arkhangelskiella spp.

Other frequent taxa are Placozygus spp. (avg. 3.38\%), Microrhabdulus spp. (avg. 2.54\%), Zeugrhabdotus spp. (avg. 2.54\%), Uniplanarius spp. (avg. $1.88 \%$ ), Reinhardtites levis (avg. 1.81\%) and Biscutum constans (avg. 1.6\%). Of these, the most abundant species are $P$. spiralis (avg. 2.06\%), B. constans (avg. $1.6 \%$ ), M. undosus (avg. 1.51\%) and P. fibuliformis (avg. 1.32\%). There is a slight negative correlation between $B$. constans and Placozygus spp., whereas $B$. constans correlates positively with Zeugrhabdotus spp. A slightly negative correlation between $\mathrm{Zeu}$ grhabdotus spp. and P. spiralis and a negligibly positive correlation between Zeugrhabdotus spp. and $P$. fibuliformis are observed.

Acknowledgements: This work has been carried out in the framework of the National Science Programme "Environmental Protection and Reduction of Risks of Adverse Events and Natural Disasters", approved by the Resolution of the Council of Ministers № 577/17.08.2018 and supported by the Ministry of Education and Science (MES) of Bulgaria (Agreement № D01-230/06.12.2018, D01-322/18.12.2019, D01$363 / 17.12 .2020)$.

\section{References}

Bown, P. R., J. R. Young. 1998. Techniques. - In: Bown, P. R. (Ed.). Calcareous Nannofossil Biostratigraphy. London, British Micropalaeontological Society Publication Series. Chapman \& Hall/Kluwer Academic Publishers, 16-28; https://doi.org/10.1007/978-94-011-4902-0_2.

Burnett, J. A. 1998. Upper Cretaceous. - In: Bown, P. R. (Ed.). Calcareous Nannofossil Biostratigraphy. London, British Micropalaeontological Society Publication Series. Chapman \& Hall/Kluwer Academic Publishers, 132-199; https:// doi.org/10.1007/978-94-011-4902-0_6.

Dabovski, H., B. Kamenov, D. Sinnyovsky, E. Vasilev, E. Dimitrova, I. Bayraktarov. 2009. Upper Cretaceous geology. - In: Zagorchev, I., Ch. Dabovski, T. Nikolov (Eds.). Geology of Bulgaria. Vol. II. Mesozoic Geology. Sofia, "Prof. Marin Drinov" Academic Press, 303-589 (in Bulgarian with English summary).

Dabovski, H., I. Zagorchev. 2009. Introduction: Mesozoic evolution and Alpine structure. Alpine structure. - In: Zagorchev, I., Ch. Dabovski, T. Nikolov (Eds.). Geology of Bulgaria. Vol. II. Mesozoic Geology. Sofia, "Prof. Marin Drinov" Academic Press, 30-37 (in Bulgarian with English abstract).

Granchovski, G. 2019. Calcareous nannofossils from the upper Campanian-Maastrichtian (Upper Cretaceous) in the Kladorub Formation (Kula tectonic zone, NW Bulgaria). Geologica Balc., 48, 1, 73-101; https://doi.org/10.52321/ GeolBalc.48.1.73.

Razmjooei, M. J., N. Thibault, A. Kanib, J. Dinarès-Turell, E. Pucéat, S. Chin. 2020. Calcareous nannofossil response to Late Cretaceous climate change in the eastern Tethys (Zagros Basin, Iran). - Palaeogeogr., Palaeoclimatol., Palaeoecol., 538, 109418; https://doi.org/10.1016/j.palaeo.2019.109418.

Stoykova, K., G. Granchovski, C. V. Ullmann. 2020. First data on the expression of the Campanian-Maastrichtian boundary event in Bulgaria: calcareous nannofossil and carbon isotope record. - C. R. Acad. bulg. Sci., 73, 12, 1711-1719; https://doi.org/10.7546/CRABS.2020.12.11.

Thibault, N. 2016. Calcareous nannofossil biostratigraphy and turnover dynamics in the late Campanian-Maastrichtian of the tropical South Atlantic. - Rev. micropaléont., 59, 5769; https://doi.org/10.1016/j.revmic.2016.01.001. 